\title{
INTERNATIONAL HUMAN RIGHTS PROTECTION AND REGIONAL INTEGRATION: EUROPEAN AND EURASIAN INTEGRATION PROCESSES COMPARED*
}

\author{
Mark Entin** \\ Dmitriy Galushko***
}

\begin{abstract}
This paper seeks to analyze some contemporary issues relating to the determination of a place of human rights protection within the integration processes in Europe and Eurasia. First, it briefly presents relevant developments regarding integration in Europe based on the examples of the Council of Europe and the European Union. Second, it proposes an analytical framework for the assessment of the protection of human rights within Eurasian integration, namely in the post-Soviet space. This assessment is carried out through the prism of existing inter-state arrangements, namely within the framework of such entities as the Commonwealth of Independent States (CIS) and the Eurasian Economic Union (EAEU). Third, the paper attempts to identify on-going problems and legal challenges concerning the protection of human rights by regional integration organizations in Europe and Eurasia and suggests some solutions to these challenges.
\end{abstract}

KEYWORDS: human rights protection, regional integration, Council of Europe, European Union, European integration, Eurasian Economic Union, Eurasian integration

* The authors would like to express their gratitude to Professor Alina Kaczorowska-Ireland, Professor of International and EU Law, University of the West Indies, Cave Hill, for her insightful and valuable comments on an earlier version of this article.

** Mark Entin, MGIMO University Department of European Law, Russia; entinmark@gmail. com.

*** Dmitriy Galushko, Voronezh State University Department of International and Eurasian Law, Russia; galushkodv@gmail.com. 


\section{INTRODUCTION}

The COVID-19 coronavirus pandemic has changed the world in which we live. It clear that humanity has done too little to effectively achieve the goals of solidarity, good governance, and the protection of human rights with a view to defeat the pandemic. However, all countries of the world have, to a greater or lesser extent, taken strong measures to limit the fundamental rights of individuals. Some limitations have been temporarily introduced on the exercise of the rights to personal integrity, freedom of association, assembly, conscience, speech, and many others. This means that as soon as life begins to return to normal, it will be necessary to begin to develop new international treaties and mechanisms in the field of protecting human rights, which would prevent a recurrence of the situation with the 2020 pandemic. These international treaties and mechanisms would need to enhance multilateral cooperation, solidarity, and mutual assistance in the fields of healthcare and prevention of pandemics. If this is not done then we would betray the memory of thousands of people whom we have lost due to poorly established international interaction and unpreparedness for emergencies in the fields of healthcare. In order to achieve such interaction and co-operation, it is extremely important to trace where, and to what extent, we are now in the field of protecting human rights especially in the light of the development of regional integration processes. This article is devoted to the analysis of this group of problems.

\section{MODERN INTERNATIONAL LEGAL SYSTEM OF PROTECTION OF HUMAN RIGHTS: A GENERAL OVERVIEW}

Nowadays issues of protection of human rights and freedoms are one of the most important problems of the domestic and foreign policy of all the states of the international community. It is the situation in the sphere of ensuring of rights and freedoms, their practical implementation that is the criterion according to which the level of democratic development of a state and society as a whole is assessed as their principles inform the content of good governance efforts: they may inform the development of legislative frameworks, policies, programs, budgetary allocations, and other measures. ${ }^{1}$

One of the realities of the modern international legal order is the recognition of human rights as an element of the object of interstate relations: the attitude of the state towards its citizens is no longer a matter of exclusively internal

UN Office of the High Commissioner for Human Rights (OHCHR), Good Governance Practices for the Protection of Human Rights, 2007, HR/PUB/07/4, p. 1. 
jurisdiction. ${ }^{2}$ On the contrary, the protection of human and civil rights is a constitutional and international legal duty of modern states, which is implemented using a system of principles, institutions, mechanisms, and legal rules directly or indirectly provided for these purposes. As the protection of such rights cannot be entrusted to individual governments, those rights must be the concern of the international community. ${ }^{3}$ The very problem of protection of human rights is a complex, multifaceted phenomenon, which in various historical periods, invariably having a political and legal content, also acquired religious, ethical, and philosophical dimensions. Hence, human rights and freedoms act as a specific normative measure of socio-cultural and economic activities of any modern state. As Samantha Besson observes, the concept of sovereignty expresses and incorporates one or many values that it seeks to implement in practice and according to which political situations should be evaluated. These values are diverse and include, among others, democracy and human rights. ${ }^{4}$

The generally recognized trend in the life of the current world community is the deepening of interstate cooperation in various fields, including the field of human rights protection, which is expressed in the development of processes of globalization and regional integration. In these circumstances states, defending their interests, simultaneously use self-restriction of own sovereign rights and transfer of their implementation to international structures that help them in the execution of the traditional functions of the state, namely the function of protection of human and civil rights. ${ }^{5}$ As a result, the problem of human rights protection goes beyond the responsibility of an individual state, turning into the agenda of the entire world community and regional integration entities, which normatively determine international legal standards, below which the state is not entitled to fall.

The international community pays significant attention to the development and promotion of human rights. Besides, the democratization of the process associated with the proclamation and protection of human rights was greatly facilitated by the adoption of several international acts concerning the consolidation, legal regulation, and development of a mechanism for the international protection of human rights in states that have signed relevant documents. However, it

2 Lukashuk, I.I.: Mezhdunarodnoe pravo. Obshhaja chast': uchebnik [International Law. General Part: Textbook], Moscow, 2005, p. 312 (in Russ.).

3 Evans, T.: The politics of human rights: A global perspective, London, Pluto Press, 2005, p. 2.

4 Besson, S.: Sovereignty in Conflict, European Integration online Papers (EIoP), Vol. 8 , 2004, N¹5, URL: http://eiop.or.at/eiop/texte/2004-015a.htm, p. 7.

5 See further: Sarooshi, D.: The Essentially Contested Nature of the Concept of Sovereignty: Implications for the Exercise by International Organizations of Delegated Powers of Government, Michigan Journal of International Law, Volume 25, Issue 4, 2004, p. 1107-1139. 
should be taken into account from the very beginning, that countries have their reasons for not consenting to certain rules of international law, in particular in the sphere of human rights protection. Those reasons may be viewed as valid by some, or even by many, but the ultimate result is a system where different countries are bound by different rules. Not only is that confusing for countries and international organizations, but it means that people are afforded different guarantees and protections depending on where they are situated in the world. That undermines two crucial foundations of most legal systems: the need for the law to have certainty and for it to be applied consistently. ${ }^{6}$

The international system for protection and observance of human rights has developed at both the universal and regional levels. The universal system for human rights protection is understood as a means of protection of human rights that are created and used by the entire international community under the auspices of the United Nations and its bodies ${ }^{7}$. Conventionally, these means can be divided into regulatory and institutional components. The first can include international legal acts containing the rules of relevant activities and formulating the rights and obligations of the respective entities (conventions, covenants, agreements, treaties, etc.), as well as international documents, which norms do not contain directly defined rights and obligations (in particular, declarations, statements, memoranda). ${ }^{8}$ The second category includes international bodies for monitoring and control of implementation of major human rights documents (commissions, committees) and protection of these rights (courts, tribunals). ${ }^{9}$

The modern system of human rights protection goes back to the 1945 conference in San Francisco, which, although it did not create a system of protection as such, nevertheless laid its legal and conceptual foundation in the UN Charter. ${ }^{10}$ Drafting the Charter, the major powers decided that the world body should be granted the competence only to promote international cooperation for the universal realization of human rights. They rejected the idea that the Organization should be given the competence to protect human rights as well. ${ }^{11}$ In addition to the Charter, many other documents were adopted within

$6 \quad$ Freedman, R.: Failing to protect: the UN and the politicisation of human rights, London, Hurst \& Company, 2014, p. 6.

7 Kaczorowska, A.: Public international law, Abingdon, New York, Routledge, 2010, p. 493.

8 Shaw, M.N.: International law, Cambridge University Press, 2008, p. 276.

$9 \quad$ Ibid., p. 303.

10 United Nations Charter. URL: https://www.un.org/en/charter-united-nations/, accessed on 15/03/2020.

11 Ramcharan, B.G.: The advent of universal protection of human rights: Theo van Boven and the transformation of the UN role. Cham, Switzerland, Springer, 2018, p. xiii. 
the UN that were different in their legal force, enshrining both general and special human rights, ${ }^{12}$ but they have a simple rationale: these human rights and fundamental freedoms must be respected, assured, and protected if the individual human being is to be secure, to develop to the fullness of his or her personality, and to breathe the air of liberty. ${ }^{13}$

In contrast to the universally accepted international standards of human rights and freedoms, the process of regionalization and the creation of standards and mechanisms for human rights protection in different regions of the world feature a large peculiarity and take a considerable period. This process is not accompanied by a denial of universal standards of human rights and freedoms and mechanisms for their protection, but by a desire to adapt and specify them concerning other socio-economic conditions for the development of different countries, their legal, cultural, historical and religious traditions. ${ }^{14}$ Thereby, all universal tools for human rights protection were taken into account in the development of the regional integration processes, in particular, in the Eurasian one.

Generally, in this regard, some scholars state, that regional organizations have been more successful in human rights protection than the UN. ${ }^{15}$ Among the regional systems for human rights protection, international legal acts, and international bodies for monitoring the observance and protection of human rights are also distinguished. One of the prominent places occupies the Euro-

12 See e.g.: Universal Declaration of Human Rights. URL: https://www.un.org/en/universal-declaration-human-rights/, accessed on 15/03/2020; International Covenant on Civil and Political Rights of 1966. URL: https://www.ohchr.org/en/professionalinterest/pages/ccpr.aspx , accessed on 15/03/2020; International Covenant on Economic, Social and Cultural Rights of 1966. URL: https://www.ohchr.org/en/professionalinterest/pages/cescr.aspx, accessed on 15/03/2020; Convention on the Prevention and Punishment of the Crime of Genocide of 1948. URL: https://treaties.un.org/Pages/ViewDetails.aspx?src=IND\&mtdsg_no=IV-1\&chapter $=4 \&$ clang=_en\#1 accessed on 15/03/2020; International Convention on the Elimination of All Forms of Racial Discrimination of 1965. URL: https://www.ohchr.org/en/professionalinterest/pages/cerd.aspx, accessed on 15/03/2020.

13 Ramcharan, B.G.: The Security Council and the protection of human rights, The Hague, New York, Martinus Nijhoff Publishers, 2002, p. 9.

14 Kartashkin, V.A.: Vzaimodejstvie universal'nyh i regional'nyh sistem zashhity prav grazhdan [The interaction of universal and regional systems for protecting the rights of citizens.], in: Abashidze, A,H., Kiseleva E.V. (eds.): Aktual'nye problemy sovremennogo mezhdunarodnogo prava: Materialy ezhegodnoj mezhvuzovskoj nauchno-prakticheskoj konferencii. Moskva, 2011 [Actual problems of modern international law: Materials of the annual inter-university scientific and practical conference. Moscow, 2011], Moscow, RUDN, 2012, ch. I, p. 11 (in Russ.).

15 Martin, F.F.: International human rights and humanitarian law: Treaties, cases, and analysis, Port Chester, NY, Cambridge University Press, 2005, p. 6. 
pean system of protection of human rights and freedoms, the basis of which is the mechanisms of international organizations such as the Council of Europe and the European Union, i.e. those structures that, under current conditions, continue to play a leading role in ensuring human rights in the European continent. The functioning of these international organizations (especially the European Union) is often identified with the concept of "regional integration". This process is characteristic of almost all regions of the world, including the Eurasian region, within the framework of which the process of Eurasian integration is developing, of which the Russian Federation is one of the founders and the most active participants.

\section{PROTECTION OF HUMAN RIGHTS IN THE FRAMEWORK OF THE EUROPEAN INTEGRATION PROCESS}

International integration in Europe and other regions of the world is a complex, lengthy process, which develops far from everywhere at the same pace. Hence the variety of legal forms of integration, the existence of many independent integration groups. In the territory of Europe the Council of Europe, of which the Russian Federation is a member, acts as an important political center for pan-European integration. The European Union brings together with the Council of Europe not only similarities in names, identical symbolism, but, most importantly, common goals: "The aim of the Council of Europe is to achieve a greater unity between its members to safeguard and realize the ideals and principles which are their common heritage and facilitating their economic and social progress" (Article 1 of the Statute of the Council of Europe). ${ }^{16}$

Immediately after the creation of the Council of Europe, there arose a question of adoption of a legally binding document, that is, an international treaty that would fix at the European level basic human rights and freedoms, which was signed on 4 November 1950 under the name of the Convention for the Protection of Human Rights and Fundamental Freedoms. ${ }^{17}$ The Convention, as noted in the preamble, was intended to become a form of "collective enforcement of certain of the rights stated in the Universal Declaration". ${ }^{18}$ Many provisions of the Convention were subsequently taken into account in the process of Eur-

16 Statute of the Council of Europe. URL: https://rm.coe.int/1680306052, accessed on 15/03/2020.

17 Convention for the Protection of Human Rights and Fundamental Freedoms of 1950. URL: https://rm.coe.int/1680063765, accessed on 15/03/2020.

18 Ibid. 
asian integration, in particular, in the text of the CIS Convention on Human Rights and Fundamental Freedoms of $1995 .^{19}$

Along with the Council of Europe, there was a creation of the European communities - the European Coal and Steel Community (ECSC), the European Economic Community (EEC), the European Atomic Energy Community (Euratom), and then the European Union (EU). Initially, in all founding treaties of these integration entities, there was no mention of the need to protect fundamental human rights and freedoms and other similar values. One of the reasons for the non-inclusion of the sphere of human rights to the founding treaties of the European Communities was precisely the fact that by that time the 1950 European Convention and the Council of Europe's jurisdictional protection, has been already in force. Besides, for a long time, the Court of Justice considered that joining the sphere of human rights to the legal order of the Communities could undermine the approval process of its supremacy over the national law of the member states. ${ }^{20}$ In its original shape, Communities proved of little relevance to the individual human rights regime, hence illustrating its strict economic nature. ${ }^{21}$ Nevertheless, so far within the ECSC framework, acts adopted by the High Authority were appealed to the European Court of Justice (ECJ) by citizens of member states if they violated their rights and freedoms guaranteed by national constitutions.

By the second half of the 1960s, the ECJ ceased to follow its initial rather nihilistic practices concerning human rights, ${ }^{22}$ refusing to interpret the acts of the Community institutions by the constitutional provisions of the member states to ensure rights and fundamental freedoms, and the institutions of the Community are not obliged to respect these rights. In its decisions in Stork ${ }^{23}$

\footnotetext{
19 Konvencija Sodruzhestva Nezavisimyh Gosudarstv o pravah i osnovnyh svobodah chelovekaб 1995 [Commonwealth of Independent States Convention on Human Rights and Fundamental Freedoms of 1995] (in Russ.). URL: http://cis.minsk.by/reestr/ru/index.html\#reestr/view/text?doc $=451$, accessed on 15/03/2020.

20 Kapustin, A. Ja.: Evropejskij Sojuz: integracija i pravo [European Union: Integration and Law], Moscow, 2000, p. 274 (in Russ.).

21 Korenica, F.: The EU accession to the ECHR: Between Luxembourg's search for autonomy and Strasbourg's credibility on human rights protection, Cham, Springer, 2015, p. 37.

22 Entin, L.M. (ed.): Evropejskoe pravo. Pravo Evropejskogo Sojuza i prav. obespech. zashhity prav cheloveka: Uchebnik [European law. European Union Law and Legal Support for the Protection of Human Rights: A Textbook], Moscow, Norma, 2007, p. 326 (in Russ.).

23 Judgment of the Court of 4 February 1959. Friedrich Stork \& Cie v High Authority of the European Coal and Steel Community. Case 1/58. URL: https://eur-lex.europa.eu/legal-content/ EN/TXT/?uri=CELEX\%3A61958CJ0001, accessed on 15/03/2020.
} 
and a few other cases, ${ }^{24}$ the ECJ decided that the High Authority is guided in its actions exclusively by Community law and should not comply with the law of the member states, noting, that "Community law, as it arises under the ECSC Treaty, does not contain any general principle, express or otherwise, guaranteeing the maintenance of vested rights". ${ }^{25}$

However, subsequently, the ECJ's position began to change, and its interpretation activities ${ }^{26}$ inevitably led to the adoption of the principle of protection of fundamental rights within the framework of the European legal order. In 1969, the ECJ ruled that this principle is a part of the general principles of Community law and is protected by the judiciary, defining that "the provision at issue contains nothing capable of prejudicing the fundamental human rights enshrined in the general principles of Community law and protected by the Court". ${ }^{27}$ Subsequently, the ECJ confirmed the need for effective implementation of human rights, ${ }^{28}$ stating that "the protection of such rights ... must be ensured within the framework of the structure and objectives of the Community". 29

In 1974, by a decision in the Nold II case, the ECJ decided that within the framework of Community law the Court should follow "International treaties for the protection of human rights, on which the member states have collaborated or of which they are signatories" ... "including in particular the Convention for the protection of human rights and fundamental freedoms of 4 November 1950 and the Protocol to that Convention of 20 March 1952". ${ }^{30}$ Thus, it was

24 Judgment of the Court of 14 May 1974. J. Nold, Kohlen- und Baustoffgroßhandlung v Commission of the European Communities. Case 4-73. URL: https://eur-lex.europa.eu/legal-content/EN/TXT/?uri=CELEX\%3A61973CJ0004, accessed on 15/03/2020.

25 Ibid.

26 See: Case C-26/62 Van Gend en Loos v. der Belastingen Administration of February 5, 1963, European Court Reports, 1963. URL:https://eur-lex.europa.eu/legal-content/EN/TX$\mathrm{T} /$ ?uri=CELEX\%3A61962CJ0026, accessed on 15/03/2020; Judgment of the Court of 15 July 1964. Flaminio Costa v E.N.E.L. Reference for a preliminary ruling: Giudice conciliatore di Milano - Italy. Case 6-64. URL: https://eur-lex.europa.eu/legal-content/EN/TXT/?uri=CELEX\%3A61964CJ0006, accessed on 15/03/2020.

27 Case C-29/69 Stauder v. Stadt Ulm of November 12, 1969, European Court Reports, 1969. URL: https://eur-lex.europa.eu/legal-content/EN/TXT/?uri=CELEX\%3A61969CJ0029, accessed on 15/03/2020.

28 See: Judgment of the Court of 17 December 1970. Internationale Handelsgesellschaft mbH v Einfuhr- und Vorratsstelle für Getreide und Futtermittel. Reference for a preliminary ruling: Verwaltungsgericht Frankfurt am Main - Germany, Case 11-70. URL: https://eur-lex.europa. eu/legal-content/EN/TXT/?uri=CELEX\%3A61970CJ0011, accessed on 15/03/2020.

29 Ibid.

30 Judgment of the Court of 14 May 1974. J. Nold, Kohlen- und Baustoffgroßhandlung v 
established a link between the legal order of the Communities and the human rights protection mechanism of the Council of Europe.

The recognition of the principle of the protection of fundamental rights within the framework of Community law took place after a political statement issued on 5 April 1977. ${ }^{31}$ The Community institutions recognized that the principles that underlie the Convention for the Protection of Human Rights and Fundamental Freedoms should also be integrated into Community law. Later these arrangements were reflected in the Communitarian primary law when the third paragraph of the preamble of the Single European Act stated that the EU member states are "determined to work together to promote democracy based on the fundamental rights recognized in the constitutions and laws of the Member States in the Convention for the Protection of Human Rights and Fundamental Freedoms and the European Social Charter".32 The Maastricht Treaty supplemented these provisions in Article F, which established that the European Union respects the fundamental rights guaranteed by the European Convention, and "as they result from the constitutional traditions common to the Member States, as general principles of Community law". ${ }^{33}$ It should be noted, that the arguments used by the ECJ earlier in the Hauer ${ }^{34}$ and Rutili ${ }^{35}$ cases have been taken into account and are specifically reflected in the contents of this article.

The protection of fundamental rights and freedoms have played an important role in the further development of the European Union legal order, thus, the Lisbon Treaty enshrined the binding legal force of the provisions on the

Commission of the European Communities, Case 4-73. URL: https://eur-lex.europa.eu/legal-content/EN/TXT/?uri=CELEX\%3A61973CJ0004, accessed on 15/03/2020.

31 Joint Declaration by the European Parliament, Council and the Commission concerning the protection of fundamental rights and the ECHR (Luxembourg, 5 April 1977). URL: https://www.europarl.europa.eu/charter/docs/pdf/jointdecl_04_77_en_en.pdf, accessed on 15/03/2020.

32 Single European Act. URL: https://eur-lex.europa.eu/legal-content/EN/TXT/PDF/?uri=CELEX:11986U/TXT\&from=EN, accessed on 15/03/2020.

33 Treaty on European Union. URL: https://europa.eu/european-union/sites/europaeu/files/ docs/body/treaty_on_european_union_en.pdf, accessed on 15/03/2020.

34 Judgment of the Court of 13 December 1979. Liselotte Hauer v Land Rheinland-Pfalz. Reference for a preliminary ruling: Verwaltungsgericht Neustadt an der Weinstraße - Germany. Prohibition on new planting of vines. Case 44/79. URL: https://eur-lex.europa.eu/legal-content/HR/TXT/?uri=CELEX:61979CJ0044, accessed on 15/03/2020.

35 Judgment of the Court of 28 October 1975. Roland Rutili v Ministre de l'intérieur. Reference for a preliminary ruling: Tribunal administratif de Paris - France. Public policy. Case 36-75. URL: https://eur-lex.europa.eu/legal-content/EN/TXT/?uri=CELEX\%3A61975CJ0036, accessed on 15/03/2020. 
principle of respect for human rights and fundamental freedoms contained in the Charter of Fundamental Rights. ${ }^{36}$ The document does not provide for the granting of new rights, but combines in one document all the rights and freedoms of EU citizens, which were enshrined in different international documents, taking into account the case law of the European Court of Human Rights and the European Court of Justice. The new document added the provisions of the 1950 European Convention not only by other economic, social and cultural rights, but also by new civil and political rights, such as the right to good governance, the right to a healthy environment, the right to protect personal data, and expanded the concept personal immunity through the prohibition of eugenic practices and human cloning for reproductive purposes.

The new list of fundamental rights does not apply in all cases of human rights violations within the European Union. It applies only to acts adopted by EU institutions and other EU bodies and EU Member States in the implementation of EU law, under paragraph 1 of Art. 51 of the Charter, if the provisions of this document do not apply in a particular case, fundamental rights must be protected at the local level in accordance with the national constitutional legislation of each member state. Besides, all EU member states have acceded to the 1950 European Convention, according to which the obligation under it does not depend on obligations under EU law. Thus, anyone can sue the European Court of Human Rights for violating one of the fundamental rights guaranteed by the Convention, after exhausting all legal remedies at the national level. Thus, the Charter complements, but does not replace, the protection provided by national constitutional law and the 1950 European Convention. ${ }^{37}$

The Lisbon Treaty also enshrined the provision on EU accession to the European Convention, explaining in detail the conditions for such accession in Protocol No. 8 attached to the treaty. Nevertheless, the Union has not yet joined the Convention, while continuing to develop its mechanism for protection of human rights and actively promoting relations between its institutional system and authorities of the Council of Europe, especially with the European Court of Human Rights. ${ }^{38}$ As noted, the relationship between Luxembourg and the Strasbourg courts is much better than is commonly thought. The courts meet

${ }_{36}$ Charter of Fundamental Rights of the European Union. URL: https://www.europarl.europa.eu/charter/pdf/text_en.pdf, accessed on 15/03/2020.

372010 report on the application of the EU Charter of Fundamental Rights. URL: https:// op.europa.eu/en/publication-detail/-/publication/3883477d-a821-40db-b01e-890439fa8942/ language-en, accessed on 15/03/2020.

38 See: Korenica, F.: The EU Accession to the ECHR: Between Luxembourg's Search for Autonomy and Strasbourg's Credibility on Human Rights Protection, Springer, 2015. - DOI: 10.1007/978-3-319-21759-8. 
regularly. They discuss issues of mutual concern. They developed a kind of modus-vivendi, which they try to follow carefully. ${ }^{39}$ The provisions of the European Convention and the practice of the European Court of Human Rights are for the ECJ only a "supporting tool" used in interpreting the provisions of the EU Charter of Fundamental Rights. The ECHR, in turn, recognizes the need to change its many years of practice on certain issues relating to the interpretation of the provisions of the ECHR, referring to the interpretation of the provisions of the Charter by the ECJ. ${ }^{40}$ Nevertheless, in recent years, the ECJ has ignored the decisions of the Strasbourg Court, forcing its own practice. ${ }^{41}$

Moreover, the European Council in Tampere has put forward the idea of creating the European Union EU Agency for Fundamental Rights to provide the institutions and other bodies of the EU and member states with ensuring "compliance with fundamental rights of both Community law and policies and implementation of the latter by member states". ${ }^{42}$ The agency was created based on EU Council Regulation No. 168/2007 $7^{43}$ and began functioning on 1 March 2007. The new institution received more powers than the former European Monitoring Centre on Racism and Xenophobia: from discrimination to the protection of human rights and fundamental freedoms at the European level, without interfering with the control powers of member states. Among other things, the Agency should work closely with the Council of Europe. ${ }^{44}$

\footnotetext{
39 Entin, M.L.: Perspektivy vzaimodejstvija Evropejskogo Sojuza i Soveta Evropy v oblasti zashhity prav cheloveka [Prospects for cooperation between the European Union and the Council of Europe in the field of human rights] (in Russ.). URL: http://alleuropa.ru/?p=2506, accessed on 15/03/2020.
}

40 Rjabova, V.O.: Vzaimodejstvie Suda Evropejskogo sojuza i Evropejskogo suda po pravam cheloveka po delam o zashhite prav cheloveka posle Lissabonskogo dogovora. Diss. ... kandidata juridicheskih nauk [Interaction of the Court of Justice of the European Union and the European Court of Human Rights in cases concerning the protection of human rights after the Lisbon Treaty. PhD Thesis]. Moscow, 2016, p. 15 (in Russ.).

41 See e.g.: O'Leary, S.: A Tale of Two Cities: Fundamental Rights Protection in Strasbourg and Luxembourg, Cambridge Yearbook of European Legal Studies, 2018, 20, 3-31. DOI:10.1017/cel.2018.3

42 Communication from the Commission - The Fundamental Rights Agency Public consultation document \{SEC(2004)1281\}, p. 5. URL: https://op.europa.eu/en/publication-detail/-/ publication/8f1ae927-2c2d-4be6-99c1-dc6eb2495187/language-en, accessed on 15/03/2020.

43 Council Regulation (EC) No 168/2007 of 15 February 2007 establishing a European Union Agency for Fundamental Rights. OJ L 53, 22.2.2007, p. 1-14.

44 Nuygens, R.: The benefit of the EU Fundamental Rights Agency within Europe's human rights regime: Are the EU and the Council of Europe clashing on their human rights protection structures?, 2007. URL: https://essay.utwente.nl/702/1/scriptie_Nuijens.pdf, accessed on $15 / 03 / 2020$. 
In general, nowadays the European regional system for human rights protection can be divided into two subsystems: within the Council of Europe and the European Union, which are in active interaction, while in some cases competing with each other. The creation of a unified system of human rights protection in the European region is complicated by disagreements and features of the functioning of the Council of Europe and the European Union, as regional international organizations with initially different goals and functioning mechanisms.

The Council of Europe's human rights protection subsystem is characterized by sophisticated and coherent regulatory and institutional components. And the human rights activity itself is a condition for the developing cooperation of states within the framework of this organization, contributing to the convergence of legal norms and principles in member states in many branches of law.

In turn, the European Union is gradually completing the formation of an autonomous (relative to the Council of Europe) human rights protection system. Within the EU, a separate body for the international protection of human rights, which would play the same role that the European Court of Human Rights performs in the Council of Europe, has not been created. On the other hand, the ECJ has played a decisive role in promoting the principle of the protection of human rights, as well as in defining its content and scope. Nevertheless, one should not underestimate the possibilities of the Court, which by its decisions created an extensive system of principles that guide national authorities and courts in deciding on cases of protecting human rights. Besides, the peculiarities of the EU human rights protection subsystem is that the ECJ, in parallel with the functions of ensuring the supremacy of EU law, also checks the acts of EU bodies for compliance with the norms of the European Convention for the Protection of Human Rights and Fundamental Freedoms, thus, creating its own practice in line with EU aims and objectives. Moreover, the active role of the Court also catalyzed the development of EU legislation in the sphere of human rights protection. Relevant provisions were not only enshrined into the founding and amending treaties of the Communities/Union, but afterwards were codified in the Charter of Fundamental Rights, in total, having created one of the main postulates of the present EU legal order. In our opinion, these trends should be undoubtedly taken into account within the developments of other regional integration processes, in particular, within Eurasian integration.

\section{HUMAN RIGHTS PROTECTION WITHIN EURASIAN INTEGRATION: CONTEMPORARY ISSUES}

Regarding the human rights protection system within the framework of the Eurasian integration process, several aspects can be distinguished for compar- 
ing not only the entire integration process with the European one, but also in the field of human rights protection. ${ }^{45}$ As in Europe, several intergovernmental international organizations were created within the Eurasian region with completely different goals in the basis of their functioning. ${ }^{46}$ First of all, it is worth mentioning the Commonwealth of Independent States (CIS) and the Eurasian Economic Union (EAEU).

As the starting point ${ }^{47}$ of regional integration processes in the post-Soviet space can be considered the conclusion of the Agreement establishing the Commonwealth of Independent States, ${ }^{48}$ signed by the leaders of Russia, Belarus and Ukraine at a meeting in Minsk on 8 December 1991. Article 1 of this Agreement establishes that the USSR as a subject of international law and geopolitical reality ceased to exist. At the same time, the creation of the CIS was announced. The republics of the former USSR formed the Commonwealth of Independent States, which was based on the principles of sovereign equality of all its members. One might argue that a referendum procedure would have been legally preferable. Moreover, less than a year before, in March 1991, an all-Union referendum had supported the maintenance of the USSR. Nonetheless, the political decision of the leaders of eleven Member States of the USSR was tacitly supported - even before its approval by the relevant representative State bodies - by the majority of the population in the above States, and was also subsequently de facto recognized by the international community ${ }^{49}$ The full legalization of the Commonwealth was completed on 22 January 1993 by the adoption of the Charter of the Commonwealth of Independent States. ${ }^{50}$

45 On general legal aspects of Eurasian integration, see further: Kembayev, Z.: Legal Aspects of Regional Integration Processes in the Post-Soviet Area, Berlin-Heidelberg, Springer-Verlag, 2009.

46 See further: Petrov, R., Kalinichenko, P.: On Similarities and Differences of the European Union and Eurasian Economic Union Legal Orders: Is There the 'Eurasian Economic Union Acquis'?, Legal Issues of Economic Integration, 2016, 43(3), pp. 295-307.

47 Glazyev, S.Yu., Chushkin, V.I., Tkachuk, S.P.: Evropejskij sojuz i Evrazijskoe jekonomicheskoe soobshhestvo: shodstvo i razlichie processov integracionnogo stroitel'stva [The European Union and the Eurasian Economic Community: similarities and differences in the processes of integration construction], Moscow, OOO «VIKOR MEDIA», 2013, p. 102-103 (in Russ.).

48 Agreement establishing the Commonwealth of Independent States (Minsk, 8 December 1991). URL: https://www.cvce.eu/en/obj/agreement_establishing_the_commonwealth_of_independent_states_minsk_8_december_1991-en-d1eb7a8c-4868-4da6-9098-3175c172b9bc. html, accessed on 15/03/2020.

49 Voitovich, S.A. Commonwealth of Independent States: An emerging institutional model, European Journal of International Law, Vol. 4, 1993, p. 405.

50 Charter of the Commonwealth of Independent States. URL: https://cis-legislation.com/ document.fwx?rgn=4132\%3Eaccessed, accessed on 15/03/2020. 
Concerning the protection of human rights, Article 3 of the CIS Charter proclaims one of the organization's goals to ensure human rights and fundamental freedoms for all, without distinction of race, ethnicity, language, religion, political or other beliefs. This norm has been specified in the Declaration of the Heads of State of the Commonwealth of Independent States on international obligations in the field of human rights and fundamental freedoms of 24 September $1993 .^{51}$ This document noted the responsibility of the member states of the Commonwealth in protecting the rights and freedoms of the individual, and also confirmed the commitment to the goals and principles enshrined in the UN Charter and the UN Universal Declaration of Human Rights. Besides, Article 5 of the Declaration stated "a firm intention to develop and conclude shortly the Convention of the Commonwealth of Independent States on $\mathrm{Hu}$ man Rights". According to this provision, on 26 May 1995, the CIS Convention on Human Rights and Fundamental Freedoms ${ }^{52}$ was adopted.

The 1995 CIS Convention enshrined a broad list of fundamental human rights, incorporating the provisions and principles of many universal and regional human rights instruments. In particular, some authors point to the high degree of similarity between the CIS Convention and the 1950 European Convention for the Protection of Human Rights and Fundamental Freedoms, concluding that the developers of the CIS Convention took the European Convention as a model..$^{53}$

The Convention was signed by Armenia, Belarus, Kyrgyzstan, Moldova, Russia and Tajikistan. Later it was ratified by Belarus, Kyrgyzstan, Russia and Tajikistan. In other words, most member states of the Commonwealth not only did not ratify the fundamental document on the protection of human rights in the Eurasian region, but did not even sign it. Among others, this can be explained by the fact that the Council of Europe has firmly insisted that the CIS countries, that intend to join it, should not sign the Convention, believing that it creates unnecessary competition with its own system for human rights protection. ${ }^{54}$

51 Declaration of the Heads of State of the Commonwealth of Independent States on international obligations in the field of human rights and fundamental freedoms of 24 September 1993 (in Russ.). URL: http://docs.cntd.ru/document/1900296, accessed on 15/03/2020.

52 CIS Convention on Human Rights and Fundamental Freedoms. https://www.unhcr.org/ protection/migration/4de4eef19/cis-convention-human-rights-fundamental-freedoms.html, accessed on 15/03/2020.

53 Kasyanov R.A., Torkunova E.A. Securing Human Rights on the Post-Soviet Space, MGIMO Review of International Relations, 2015, 5(44), p. 59 (in Russ.).

54 See: Co-existence of the Convention on Human Rights and Fundamental Freedoms of the Commonwealth of Independent States and the European Convention on Human 
In addition to the 1995 Convention, a large number of international treaties were signed within the CIS regarding human rights in certain areas or the rights of certain categories of persons.$^{55}$ On 24 September 1993, along with the adoption of the Declaration of the Heads of State of the Commonwealth of Independent States on international obligations in the field of human rights and fundamental freedoms, the Regulation on the CIS Human Rights Commission was approved by a decision of the Council of Heads of State. This Regulation subsequently became an integral part of the 1995 CIS Convention.

Article 33 of the CIS Charter states, that the Commission is an advisory body to the Commonwealth. Besides, the CIS Human Rights Commission, under article 34 of the Convention, monitors the implementation of this Convention. The Regulation on the Commission enshrined norms on its composition and organization of work, on the procedure for considering appeals of the parties, as well as the procedure for considering appeals of individuals and non-governmental organizations. However, to date, the Human Rights Commission has never been created. As a result, the 1995 CIS Convention lacks an effective control mechanism for its implementation. The Economic Court, created by the CIS, has never possessed powers in the field of human rights protection, but, based on its name, performs completely different functions. In our opinion, this state of affairs on the one hand reflects the attitude of member states towards international cooperation in the field within the framework of the Commonwealth, and, on the other hand, the state of affairs of the Eurasian integration process within the framework of this international organization.

In general, by developing the process of Eurasian integration, some countries stranded for the transformation of the CIS into a means for comprehensive closer economic and political integration, while others viewed the CIS as a transitional formation, which was supposed to contribute to the development of the former Soviet republics as full-fledged independent states. Therefore, the cooperation of member states within the CIS was not uniform and comprehensive. Over time, closer relations began to develop between some states; individual CIS members moved to agreeing on common positions outside the

Rights: Report. URL: http://assembly.coe.int/nw/xml/XRef/X2H-Xref-ViewHTML.asp?FileID=9298\&lang=EN, accessed on 15/03/2020.

55 E.g.: Convention on provision for rights of persons belonging to national minorities, 1994; Agreement on guarantees of the rights of CIS citizens in the field of pension provision, 1992; Agreement on Priority Measures for the Protection of Victims of Armed Conflict, 1993; Agreement on cooperation in the field of labor protection, 1994; Agreement on cooperation in the field of labor migration and social protection of migrant workers, 1994, and several others. 
Commonwealth. ${ }^{56}$ Nevertheless, attention to the protection of human rights can be traced at all stages of Eurasian integration.

So, on 29 March 1996, a Treaty on deepening integration in the economic and humanitarian fields was signed between Russia, Belarus, Kazakhstan and Kyrgyzstan. ${ }^{57}$ Article 1 established that to create in the future the Community of integrated states, the Parties decided to direct joint efforts to stepwise deepen integration of the Parties to this Treaty in the economy, science, education, culture, social sphere and other fields, subject to the sovereignty of the Parties, the principles of equality and mutual benefit, inviolability of state borders existing between them, non-interference in each other's internal affairs. One of the main goals of integration was announced to consistently improve living conditions, protect the rights and freedoms of the individual, and achieve social progress.

Subsequently, the Treaty on the Customs Union and the Common Economic Space was adopted of 26 February 1999. ${ }^{58}$ It does not contain a direct reference to the protection of human rights and fundamental freedoms, but it does contain a provision on the free movement of citizens of member states within the Common Economic Space, which implies the abolition of any discrimination against citizens of the Parties and the creation of a unified legal regime regarding employment, remuneration, and other conditions labor and employment (Article 39). It is especially noted that for these purposes the Parties will sign the relevant agreements.

After many years, on 18 November 2011 the Declaration on Eurasian Economic Integration ${ }^{59}$ established that the Common Economic Space is based on the principles of observance of universally recognized norms of international law, including respect for the sovereignty and equality of states, affirmation of fundamental human rights and freedoms, the rule of law and market economics. These declarative provisions were partially implemented in the Eurasian Economic Union, which founding treaty was signed on 29 May 2014. ${ }^{60}$ This

56 Malfliet K., Verpoest L., Vinokurov E.: Conclusion: Challenges of Integration - the EU, the CIS and Russia, in: Malfliet K., Verpoest L., Vinokurov E. (eds) The CIS, the EU and Russia. Studies in Central and Eastern Europe, London, Palgrave Macmillan, 2007, p. 236.

57 Treaty on deepening integration in the economic and humanitarian fields was signed between Russia, Belarus, Kazakhstan and Kyrgyzstan (in Russ.). URL: http://docs.cntd.ru/ document/1901125, accessed on 15/03/2020.

58 Treaty on the Customs Union and the Common Economic Space was adopted of 26 February 1999 (in Russ.). URL: http://www.evrazes.com/docs/view/128, accessed on 15/03/2020.

59 Declaration on Eurasian Economic Integration (in Russ.). URL: http://news.kremlin.ru/ ref_notes/1091, accessed on 15/03/2020.

60 Treaty on the Eurasian Economic Union. URL: https://www.un.org/en/ga/sixth/70/docs/ 
document directly indicates the establishment of the Union based on, inter alia, "the need for unconditional respect for the rule of constitutional rights and freedoms of man and national", aimed at creating "proper conditions for sustainable economic development of the Member States to improve the living standards of their population". ${ }^{61}$ The content of the Treaty reflects the economic character of integration of states within the framework of the EAEU, and it does not include provisions related to the protection of human rights. However, human rights issues in this document are provided in the light of the EAEU aims, in particular, connected with the economic sphere.

Besides, referring to the experience of the development of European integration within the European Communities / Union, it can be assumed that the competence of the EAEU, initially exclusively economic, may eventually be expanded in the context of integration successes. This is also confirmed by the content of Article 5 of the Treaty, Part 1 of which establishes that "the Union shall have jurisdiction within the scope and limits determined under this Treaty and international treaties within the Union". Thus, it is clear that the exhaustive list of areas of competence and powers of the EAEU is not fixed in the Treaty, and, therefore, it can be supplemented / changed. In any case, as indicated, it will take time for the human rights theme in the framework of the EAEU to be fully manifested. This requires political will and real successes in the field of economic integration, since as the regulated social relations expand and become more complicated, a clash of the integration interests of the EAEU and the private interests of a particular person is possible. The faster economic integration develops, the greater the relevance of the issue of the need to guarantee human rights at the Union level. ${ }^{62}$

Thus, arises the question of the institutional component of the human rights protection system in the framework of the processes of Eurasian integration, in particular, the EAEU. As noted above, the CIS Human Rights Commission is unlikely to be ever created, and the opinions on improving the structure and work of the CIS Economic Court ${ }^{63}$ in our opinion, have already lost their topicality and relevance to today's agenda of Eurasian integration. In this context,

\footnotetext{
treaty_on_eeu.pdf, accessed on 15/03/2020.

61 Ibid.

62 Kasyanov R.A., Torkunova E.A.: Securing Human Rights on the Post-Soviet Space, MGIMO Review of International Relations, 2015, 5(44), p. 57 (in Russ.).

63 See: Stojakin, S.G.: Sotrudnichestvo v sfere obespechenija prav i svobod cheloveka v SNG i ES kak vektor integracii: opyt sravnitel'nogo analiza [Cooperation in the field of ensuring human rights and freedoms in the CIS and the EU as a vector of integration: comparative analysis experience], Vestnik TjumGU, Pravo [Proceedings of TjumSU, Law], 2014, 3, p. 173-181 (in Russ.).
} 
three options for the development of human rights institutions in the Eurasian region can be distinguished.

Firstly, it is an expansion of the competence of the EAEU Court and its extension to the sphere of human rights protection. In many respects, this option depends in general on the expansion of the competence of the Eurasian Economic Union, as indicated above. According to paragraphs 1 and 2 of the Statute of the EAEU Court (Appendix No. 2 to the Treaty on the EAEU), the EAEU Court is a judicial body of the EAEU, the purpose of which is to ensure, by the provisions of the Statute, the international treaties within the framework of the Union, international treaties of the Union with a third party and decisions of the organs of the Union, that is, the communitarian "Union law", as defined in Art. 6 of the Treaty on the EAEU. However, as is the case with the competence of the entire Union, the Statute of the EAEU Court also provides for the possibility of expanding the competence of the Court. In particular, Article 40 establishes that member states may include in the jurisdiction of the Court any other disputes, the resolution of which by the Court is expressly provided for 9 by the Treaty, international treaties within the Union, and international treaties of the Union with a third party or other international treaties between the member states.

In this regard, one can also point to proposals for improvement of the activities of the CIS Economic Court in the context of human rights protection that have been previously expressed and which can be applied to the EAEU Court. According to some scholars, the solution to this problem is seen in the creation of the Commonwealth Human Rights Court "as an independent judicial body or as a special board of the CIS Economic Court already existed in the Commonwealth". ${ }^{64}$

Much will depend on the function of the EAEU Court as a human rights institution. If the issues of protection of human rights within the framework of Eurasian integration remain outside the scope of the EAEU Court, other judicial bodies will deal with this, which will create a threat to the unity, autonomy, and uniform enforcement of EAEU law. The EAEU Court is the custodian of Union law. The effectiveness of integration largely depends on its activity and authoritativeness. As noted, "the real role of the judiciary in integration is more constructive and creative: the court cements the foundations of integration" ${ }^{65}$ Accordingly, the EAEU Court should take into account the experience

64 Kleandrov, M.I.: O sudebnom mehanizme zashhity prav rossijanina v prostranstve SNG [On the judicial mechanism for protecting the rights of Russians in the CIS], Moscow Journal of International Law, 1998, 2, p.34 (in Russ.).

65 Tolstykh, V.L. (ed.): Instituty mezhdunarodnogo pravosudija [International Justice 
of the EU Court of Justice, which, by its decisions, has practically formulated the principle of protection of fundamental human rights in the integration legal order of the European Union.

To be fair, some aspects of this issue have already been announced in the Court itself, albeit at an unofficial level. So Judge Chaika K.L. indicates that, on the basis that the right to judicial protection is one of the fundamental human rights guaranteed by the Universal Declaration of Human Rights, the Convention for the Protection of Human Rights and Fundamental Freedoms, as well as the Constitutions of all member states, it appears that as part of the work on amending the EAEU Treaty should be also discussed the provision of the right to appeal to the Court by individuals. It should be noted that this approach is consistent with the practice of other integration entities, for example, the European Union (Paragraph 4 of Article 263 of the Treaty on the Functioning of the European Union). ${ }^{66}$ In any case, a lot will depend on the EAEU Court, how much it will be able to declare itself as an institution, ready not only in words but in practice to defend and protect human rights in the context of Eurasian integration. ${ }^{67}$

Secondly, it is the expansion of cooperation between the established national human rights authorities, in particular, between the Ombudsmen. In this regard, the development of the Eurasian Alliance of Ombudsmen seems promising, the decision on the creation of which was adopted in November 2017 at the initiative of Russia and Kyrgyzstan. According to the Russian Ombudsman T.N. Moskalkova, "it is very important that within the framework of the new integration community we get a friendly platform for the exchange of experience" ${ }^{68}$ Interstate cooperation to protect human rights is especially necessary

Institutions], Moscow, 2014, p. 253 (in Russ.).

${ }^{66}$ Chajka, K.L.: Usilenie jeffektivnosti prava Evrazijskogo jekonomicheskogo sojuza cherez sovershenstvovanie pravovyh osnov dejatel'nosti Suda Evrazijskogo jekonomicheskogo sojuza i Evrazijskoj jekonomicheskoj komissii [Strengthening the effectiveness of the law of the Eurasian Economic Union through improving the legal framework for the activities of the Court of the Eurasian Economic Union and the Eurasian Economic Commission], in: Bugaeva, A.S., Entin, K.V. (eds.) Mezhdunarodnoe pravosudie i ukreplenie integracionnyh processov : Mezhdunar. konf. (18-19 okt. 2018 g., Minsk) : sb. materialov [International justice and the strengthening of integration processes: Intern. conf.(October 18-19, 2018, Minsk): collection of materials], Minsk, Chetyre chetverti, 2019, p. 132 (in Russ.).

67 Kozheurov, Ja.C.: Perspektivy vzaimootnoshenij Evropejskogo Suda po pravam cheloveka i Evrazijskogo jekonomicheskogo Sojuza [Prospects for the relationship of the European Court of Human Rights and the Eurasian Economic Union], Actual problems of Russian law, 11, 2015, p. 188 (in Russ.).

68 Moskal'kova, T.N.: Institut upolnomochennyh po pravam cheloveka v rossijskoj nacional'noj sisteme zashhity prav cheloveka [The Institute of Ombudsmen for Human Rights in 
in the context of politicizing of human rights issues. In these conditions, it is the ombudsmen of different countries that seem to take on a mission to promote, develop respect for human rights and fundamental freedoms for all, without distinction of citizenship, race, gender, language and religion, that is, they should be the factor uniting different states in protecting the rights and freedoms of a particular person. ${ }^{69}$

And thirdly, this is the establishment of a separate specialized body within the EAEU. In our opinion, it is advisable to take into account the experience of the European Union and its Fundamental Rights Agency. The creation of such a body in the EAEU would, in our opinion, not only contribute to strengthening the protection of human rights in the territory of the member states of the Union, but would also improve its functioning, the activities of the EAEU bodies and interaction with member states on the entire spectrum of issues of the Union's competence. For example, some scholars made fair judgments about the competition of the EAEU Court and the Constitutional Court of Russia, which from the category of theoretical issues has already become a reality. Thus, in several decisions, the Constitutional Court ruled that the Customs Code of the Customs Union, which has been in force in the EAEU, is applied on the territory of Russia in accord with the interpretation given to it by the Constitutional Court. Moreover, in the decision of 3 March 2015, the Constitutional Court declared its right to check the EAEU Commission's acts for their compliance with the Constitution of Russia, on the basis that only it solves the constitutionality of the rules in force in the Russian legal order. This legal order includes not only national norms, but also international law, including the Treaty on the Eurasian Economic Union and acts of the EAEU Commission. From this, the Constitutional Court concluded that it has the right to consider the constitutionality of the EAEU Commission's acts, although this possibility is not directly enshrined in the Russian Constitutional Law on the Constitutional Court (which is not surprising, since the law was adopted in 1994, when no one else thought about the Eurasian Union)..$^{70}$

the Russian National System for the Protection of Human Rights], in: Moskal'kova, T.N. (ed.) Problemy zashhity prav cheloveka na evrazijskom prostranstve: obmen luchshimi praktikami ombudsmenov : materialy mezhdunar. nauchno-praktich. konf. (Moskva, 5 dekabrja 2017 g.) [Problems of protecting human rights in the Eurasian space: the exchange of best practices of the Ombudsmen: international materials. scientific and practical conf. (Moscow, December 5, 2017)], Moscow, MGIMO-Universitet, 2018, p. 21 (in Russ.).

$69 \quad$ Ibid, p. 20.

70 Ispolinov, A.S.: Statut Suda EAJeS kak otrazhenie opasenij i somnenij gosudarstv-chlenov Evrazijskogo jekonomicheskogo Sojuza [Statute of the EAEU Court as a reflection of the concerns and doubts of the member states of the Eurasian Economic Union], Pravo. Zhurnal Vysshej shkoly jekonomiki [Law. Higher School of Economics Journal], 4, 2016, p. 163 (in Russ.). 
According to the Constitutional Court, membership in interstate associations should not lead to a violation of human rights and should not threaten the foundations of the constitutional system. Thus, the Court pointed out two possible grounds for its control over the decisions of the EAEU Commission, and the main one is the issue of protection of human rights. According to the Constitutional Court, Russia's participation in the EAEU does not exempt Russia from its constitutional obligation to protect human rights. Otherwise, based on the principle of pacta sunt servanda, Russia's obligation to give priority to international treaties in the event of a conflict with national norms may result in an unconditional desire to fulfill its obligations to the detriment of human rights. ${ }^{71}$

The elimination of these contradictions in relations with the authorities of the EAEU member states would be facilitated, even partially, by the work of a consultative and advisory body similar in function to the EU Agency for Fundamental Rights, which would monitor the observance of human rights when applying the law of the Eurasian Economic Union.

However, the experience of the European Union should be taken into account. Positive experience will allow using all the best that has been created in the EU and negative experience will make it possible to avoid repeating EU mistakes caused by the unjustified deepening of integration. This experience is necessary to make the Eurasian integration project more successful and sustainable, to avoid predictable mistakes, and to use certain solutions that proved their viability. Nevertheless, the EU experience is extremely important for Russia and the development of Eurasian integration. ${ }^{72}$

\section{CONCLUSION}

Both in Europe and in the Eurasian region, the above-mentioned international regional organizations have a differing approach to the protection of human rights. This is because of historical reasons the protection of human rights initially had uneven normative consolidation. At present, the European Union in a constructive manner to achieve the objectives for which it was created, consequently, provides application and interpretation of human rights in different ways from that of the European Court of Human Rights.

\footnotetext{
71 Decision of the Constitutional Court of the Russian Federation No. 417-O of 3 March 2015, Bulletin of the Constitutional Court of the Russian Federation, 2015, No. 3 (in Russ.). URL: https://www.garant.ru/products/ipo/prime/doc/70802050/, accessed on 15/03/2020.

72 Entin, M., Voynikov, V.: Institutional and Legal Development of EAEU and EU in Comparative Perspective, Russian Law Journal, 7(3), 2019, p. 164. - DOI: 10.17589/2309-86782019-7-3-155-168.
} 
It is worth noting that the European Union did not, during its early years, wish to be involved in the protection of human rights. More than half a century ago, the principle of protecting human rights within the framework of the EU legal order was first rejected, and then gradually developed, mainly through the ECJ's case law. In particular, the principle of supremacy of EU law made it necessary for the ECJ and the Member States to develop a human rights dimension of the Union which has culminated with the adoption of the Fundamental Charter of the European Union, which has the same legal value as EU treaties. In general, the principle of protecting the fundamental rights and freedoms of citizens has come a long way within the framework of integration legal order, and its development is still ongoing.

Within the processes of Eurasian integration, not much attention was paid to the protection of human rights, and many elements of the protection have been neither implemented, nor fully formulated with the result that they need to be improved and developed. It is not surprising therefore that the activities of both the Commonwealth of Independent States and the Eurasian Economic Union in the area of the protection of human rights are insufficiency at both the regulatory and institutional levels. However, accepting the great potential for the development of the EAEU, its implementation may well be based on the tools of constitutionalization of the European Union, in particular, in the sphere of human rights protection. In this regard, pointing to the EU experience, it would be important to invite the EAEU Court to express itself quite definitely about the place and the role of human rights in the EAEU legal order. This would add legal legitimacy to the EAEU, in particular, and to the entire Eurasian integration process, in general.

\section{LITERATURE}

1. Bekemans, L.: The Idea of Europe: Identity-building from a Historical Perspective, International Academic Publishers Peter Lang, Brussels, Berlin, Bern, Frankfurt am Main, New York, Oxford, Wien, 2012, p. 65-81.

2. Besson, S.: Sovereignty in Conflict, European Integration online Papers (EIoP), Vol. 8, 2004, N¹5, URL: http://eiop.or.at/eiop/texte/2004-015a.htm, accessed on $15 / 03 / 2020$.

3. Chajka, K.L.: Usilenie jeffektivnosti prava Evrazijskogo jekonomicheskogo sojuza cherez sovershenstvovanie pravovyh osnov dejatel'nosti Suda Evrazijskogo jekonomicheskogo sojuza i Evrazijskoj jekonomicheskoj komissii [Strengthening the effectiveness of the law of the Eurasian Economic Union through improving the legal framework for the activities of the Court of the Eurasian Economic 
Union and the Eurasian Economic Commission], in: Bugaeva, A.S., Entin, K.V. (eds.) Mezhdunarodnoe pravosudie i ukreplenie integracionnyh processov: Mezhdunar. konf. (18-19 okt. 2018 g., Minsk): sb. materialov [International justice and the strengthening of integration processes: Intern. conf. (October 18-19, 2018, Minsk): collection of materials], Minsk, Chetyre chetverti, 2019, p. 132 (in Russ.).

4. Entin, L.M. (ed.): Evropejskoe pravo. Pravo Evropejskogo Sojuza i prav. obespech. zashhity prav cheloveka: Uchebnik [European law. European Union Law and Legal Support for the Protection of Human Rights: A Textbook], Moscow, Norma, 2007, p. 326 (in Russ.).

5. Entin, M.L.: Perspektivy vzaimodejstvija Evropejskogo Sojuza i Soveta Evropy v oblasti zashhity prav cheloveka [Prospects for cooperation between the European Union and the Council of Europe in the field of human rights] (in Russ.). URL: http://alleuropa.ru/?p=2506, accessed on 15/03/2020.

6. Entin, M., Voynikov, V.: Institutional and Legal Development of EAEU and EU in Comparative Perspective, Russian Law Journal, 7(3), 2019, p. 164.

- DOI: https://doi.org/10.17589/2309-8678-2019-7-3-155-168

7. Evans, T.: The politics of human rights: A global perspective, London, Pluto Press, 2005.

8. Freedman, R.: Failing to protect: the UN and the politicisation of human rights, London, Hurst \& Company, 2014.

9. Glazyev, S.Yu., Chushkin, V.I., Tkachuk, S.P.: Evropejskij sojuz i Evrazijskoe jekonomicheskoe soobshhestvo: shodstvo i razlichie processov integracionnogo stroitel'stva [The European Union and the Eurasian Economic Community: similarities and differences in the processes of integration construction], Moscow, OOO «VIKOR MEDIA», 2013, p. 102-103 (in Russ.).

10. Ispolinov, A.S.: Statut Suda EAJeS kak otrazhenie opasenij i somnenij gosudarstv-chlenov Evrazijskogo jekonomicheskogo Sojuza [Statute of the EAEU Court as a reflection of the concerns and doubts of the member states of the Eurasian Economic Union], Pravo. Zhurnal Vysshej shkoly jekonomiki [Law. Higher School of Economics Journal], 4, 2016, p. 163 (in Russ.).

11. Kaczorowska, A.: Public international law, Abingdon, New York, Routledge, 2010.

12. Kapustin, A. Ja.: Evropejskij Sojuz: integracija i pravo [European Union: Integration and Law], Moscow, 2000, p. 274 (in Russ.).

13. Kartashkin, V.A.: Vzaimodejstvie universal'nyh i regional'nyh sistem zashhity prav grazhdan [The interaction of universal and regional systems for protecting the rights of citizens.], in: Abashidze, A,H., Kiseleva E.V. (eds.): Aktual'nye problemy sovremennogo mezhdunarodnogo prava: Materialy ezhegodnoj mezhvuzovskoj nauchno-prakticheskoj konferencii. Moskva, 2011 [Actual problems of modern international law: Materials of the annual inter-university scientific and practical conference. Moscow, 2011], Moscow, RUDN, 2012, ch. I, p. 11 (in Russ.). 
14. Kasyanov, R.A., Torkunova, E.A.: Securing Human Rights on the Post-Soviet Space, MGIMO Review of International Relations, 2015, 5(44), p. 59 (in Russ.).

15. Kembayev, Z.: Legal Aspects of Regional Integration Processes in the Post-Soviet Area, Berlin-Heidelberg, Springer-Verlag, 2009.

- DOI: https://doi.org/10.1007/978-3-540-87652-6

16. Kleandrov M.I.: O sudebnom mehanizme zashhity prav rossijanina v prostranstve SNG [On the judicial mechanism for protecting the rights of Russians in the CIS], Moscow Journal of International Law, 1998, 2, p.34 (in Russ.).

17. Korenica, F.: The EU accession to the ECHR: Between Luxembourg's search for autonomy and Strasbourg's credibility on human rights protection, Cham, Springer, 2015, p. 37.

- DOI: https://doi.org/10.1007/978-3-319-21759-8

18. Kozheurov, Ja.C.: Perspektivy vzaimootnoshenij Evropejskogo Suda po pravam cheloveka i Evrazijskogo jekonomicheskogo Sojuza [Prospects for the relationship of the European Court of Human Rights and the Eurasian Economic Union], Actual problems of Russian law, 11, 2015, p. 188 (in Russ.).

19. Lukashuk, I.I.: Mezhdunarodnoe pravo. Obshhaja chast': uchebnik [International Law. General Part: Textbook], Moscow, 2005 (in Russ.).

20. Malfliet, K., Verpoest, L., Vinokurov, E.: Conclusion: Challenges of Integration - the EU, the CIS and Russia, in: Malfliet K., Verpoest L., Vinokurov E. (eds) The CIS, the EU and Russia. Studies in Central and Eastern Europe, London, Palgrave Macmillan, 2007, p. 236.

- DOI: https://doi.org/10.1057/9780230210998

21. Martin, F.F.: International human rights and humanitarian law: Treaties, cases, and analysis, Port Chester, NY, Cambridge University Press, 2005, p. 6.

22. Moskal'kova, T.N.: Institut upolnomochennyh po pravam cheloveka v rossijskoj nacional'noj sisteme zashhity prav cheloveka [The Institute of Ombudsmen for Human Rights in the Russian National System for the Protection of Human Rights], in: Moskal'kova, T.N. (ed.) Problemy zashhity prav cheloveka na evrazijskom prostranstve: obmen luchshimi praktikami ombudsmenov : materialy mezhdunar. nauchno-praktich. konf. (Moskva, 5 dekabrja 2017 g.) [Problems of protecting human rights in the Eurasian space: the exchange of best practices of the Ombudsmen: international materials. scientific and practical conf. (Moscow, December 5, 2017)], Moscow, MGIMO-Universitet, 2018, p. 21 (in Russ.).

23. Nuygens, R.: The benefit of the EU Fundamental Rights Agency within Europe's human rights regime: Are the EU and the Council of Europe clashing on their human rights protection structures?, 2007. URL: https:/essay.utwente.nl/702/1/ scriptie_Nuijens.pdf, accessed on 15/03/2020.

24. O'Leary, S.: A Tale of Two Cities: Fundamental Rights Protection in Strasbourg and Luxembourg, Cambridge Yearbook of European Legal Studies, 2018, 20, 3-31.

- DOI: https://doi.org/10.1017/cel.2018.3. 
25. Petrov, R., Kalinichenko, P.: On Similarities and Differences of the European Union and Eurasian Economic Union Legal Orders: Is There the 'Eurasian Economic Union Acquis'?, Legal Issues of Economic Integration, 2016, 43(3), pp. 295-307.

26. Ramcharan, B.G.: The Security Council and the protection of human rights, The Hague, New York, Martinus Nijhoff Publishers, 2002.

27. Ramcharan, B.G.: The advent of universal protection of human rights: Theo van Boven and the transformation of the UN role. Cham, Switzerland, Springer, 2018. - DOI: https://doi.org/10.1007/978-3-030-02221-1

28. Rjabova, V.O.: Vzaimodejstvie Suda Evropejskogo sojuza i Evropejskogo suda po pravam cheloveka po delam o zashhite prav cheloveka posle Lissabonskogo dogovora. Diss. ... kandidata juridicheskih nauk [Interaction of the Court of Justice of the European Union and the European Court of Human Rights in cases concerning the protection of human rights after the Lisbon Treaty. PhD Thesis]. Moscow, 2016, p. 15 (in Russ.).

29. Sarooshi, D.: The Essentially Contested Nature of the Concept of Sovereignty: Implications for the Exercise by International Organizations of Delegated Powers of Government, Michigan Journal of International Law, Volume 25, Issue 4, 2004, p. 1107-1139.

30. Shaw, M.N.: International law, Cambridge University Press, 2008.

31. Stojakin, S.G.: Sotrudnichestvo v sfere obespechenija prav i svobod cheloveka v SNG i ES kak vektor integracii: opyt sravnitel'nogo analiza [Cooperation in the field of ensuring human rights and freedoms in the CIS and the EU as a vector of integration: comparative analysis experience], Vestnik TjumGU, Pravo [Proceedings of TjumSU, Law], 2014, 3, p. 173-181 (in Russ.).

32. Tolstykh, V.L.: (ed.) Instituty mezhdunarodnogo pravosudija [International Justice Institutions], Moscow, 2014, p. 253 (in Russ.).

33. UN Office of the High Commissioner for Human Rights (OHCHR), Good Governance Practices for the Protection of Human Rights, 2007, HR/PUB/07/4.

34. Voitovich, S.A.: Commonwealth of Independent States: An emerging institutional model, European Journal of International Law, Vol. 4, 1993, p. 405.

- DOI: https://doi.org/10.1093/oxfordjournals.ejil.a035838. 
